Abstracta Iranica Abstracta Iranica

Revue bibliographique pour le domaine irano-aryen

Volume 25 | 2004

Comptes rendus des publications de 2002

\title{
« Small and medium-sized enterprises in the transition economy of Uzbekistan: conditions and perspectives ». Central Asian Survey, 19/2, 2000, pp. 281-296.
}

Thierry Coville

\section{(2) OpenEdition}

Journals

Édition électronique

URL : http://journals.openedition.org/abstractairanica/5216

DOI : 10.4000/abstractairanica.5216

ISSN : 1961-960X

Éditeur :

CNRS (UMR 7528 Mondes iraniens et indiens), Éditions de l'IFRI

Édition imprimée

Date de publication : 15 mai 2004

ISSN : 0240-8910

Référence électronique

Thierry Coville, « «Small and medium-sized enterprises in the transition economy of Uzbekistan:

conditions and perspectives ». Central Asian Survey, 19/2, 2000, pp. 281-296. », Abstracta Iranica [En

ligne], Volume 25 | 2004, document 347, mis en ligne le 15 mars 2006, consulté le 25 septembre 2020. URL : http://journals.openedition.org/abstractairanica/5216 ; DOI : https://doi.org/10.4000/ abstractairanica. 5216

Ce document a été généré automatiquement le 25 septembre 2020.

Tous droits réservés 


\section{«Small and medium-sized enterprises in the transition} economy of Uzbekistan: conditions and perspectives ». Central Asian Survey, 19/2, 2000, pp. 281-296.

Thierry Coville

Cet article porte sur la situation des PME en Ouzbékistan. Outre le fait que le travail est trop descriptif, l'A. se contente souvent de présenter des arguments les uns à la suite des autres sans effectuer la moindre sélection entre eux. Le seul élément véritablement intéressant de ce travail est l'accent mis sur les difficultés des PME ouzbeks à obtenir des crédits bancaires: les banques ouzbeks semblent en effet proposer des taux d'intérêt très élevés (au moins $10 \%$ en termes réels). En outre, elles demandent des garanties très élevées (d'une valeur représentant 120 à $150 \%$ du prêt).

INDEX

Thèmes : 14.3. Asie centrale 
AUTEURS

THIERRY COVILLE

Paris 